\title{
The FixM Flavoprotein Modulates Inhibition by AICAR or 5'AMP of Respiratory and Nitrogen Fixation Gene Expression in Sinorhizobium meliloti
}

\author{
Céline Cosseau, Anne Marie Garnerone, and Jacques Batut \\ Laboratoire de Biologie Moléculaire des Relations Plantes Microorganismes. UMR215 CNRS-INRA, BP27, 31326 \\ Castanet-Tolosan Cedex, France
}

Submitted 2 January 2002. Accepted 4 March 2002.

\begin{abstract}
AICAR, a purine-related metabolite, was recently shown to inhibit respiratory and nifA gene expression in Sinorhizobium meliloti. Here, we demonstrate that AICAR has essentially no or little effect in a wild-type $S$. meliloti strain and inhibits respiratory and nitrogen fixation gene expression only in specific mutant backgrounds. We have analyzed in detail a mutant in which addition of AICAR inhibited fixK, fixN, fixT, and nifA expression. The corresponding gene, fixM, is located just downstream of fix $K_{1}$ on $\operatorname{pSym} A$ megaplasmid and encodes a flavoprotein oxidoreductase. 5'AMP, a structural analogue of AICAR, mimicked AICAR effect as well as the nucleoside precursors AICAriboside and adenosine. The mode of action of AICAR and 5'AMP in vivo was investigated. We demonstrate that AICAR does not affect FixK transcriptional activity and instead regulates fixK and nifA gene expression. We hypothesize that AICAR and 5'AMP may modulate, possibly indirectly, the activity of the FixLJ two-component regulatory system. The possible physiological roles of AICAR, 5'AMP, and fixM in the context of symbiosis are discussed.
\end{abstract}

The interaction between rhizobia and their host plants culminates in the formation of specialized organs called nodules in which differentiated bacteria fix nitrogen to the benefit of the host plant. Symbiotic expression of most of the nitrogen fixation genes identified so far in Sinorhizobium meliloti is under both positive and negative control. A regulatory cascade, controlled by the two-component regulatory system FixLJ, activates expression of nitrogen fixation genes in response to microoxic conditions (David et al. 1988), such as those that prevail inside the nodule (Soupène et al. 1995). Under microoxic conditions, the sensor histidine kinase FixL autophosphorylates from ATP and transfers its phosphate to the FixJ transcriptional regulator protein (Gilles-Gonzalez et al. 1991; Reyrat et al. 1993). Phosphorylated FixJ then activates transcription of two intermediate regulatory genes, nifA and fixK, that both encode transcriptional regulators. NifA mediates activation of nif and fix genes involved in nitrogenase biosynthesis and functioning, whereas FixK, a member of the Crp/Fnr family, activates expression of fixNOQP genes involved in the synthesis of a respiratory oxi-

Corresponding author: Jacque Batut; Telephone: 33561285054; Fax: 33561285061; E-mail:jbatut@ toulouse.inra.fr.

This article is in the public domain and not copyrightable. It may be freely reprinted with customary crediting of the source. The American Phytopathological Society, 2002. dase complex (Batut et al. 1989). FixK also controls expression of a gene, fixT, that negatively affects expression of FixLJ-dependent genes by inhibiting FixL autophosphorylation (Foussard et al. 1997; Garnerone et al. 1999). The repressor activity of FixT was abolished in an asnO mutant of $S$. meliloti, thus suggesting the existence of a yet-to-be identified physiological signal associated with fixT (Berges et al. 2001).

Very recently, Soberón and associates (2001) reported that AICAR, a purine intermediate, down-regulates fixN, fixT, fixK, and nifA expression in S. meliloti, following their initial work on Rhizobium etli (Soberón et al. 1997). Previously, infection of bean by $R$. etli was shown to require production of AICAR (Newman et al. 1995). Besides this, little is known about AICAR in prokaryotes as compared with eukaryotes. In animal cells, AICAR (also sometimes called ZMP) stimulates AMPactivated protein kinases (Corton et al. 1995), thereby inhibiting lipolysis and lipogenesis (Henin et al. 1995; Sullivan et al. 1994). AICAR also inhibits glycolysis (Vincent et al. 1992) and gluconeogenesis (Vincent et al. 1991). In plants, AICAR activates NADH-nitrate reductase, sucrose phosphate synthetase, and glutamine synthetase in vivo (Huber and Kaiser 1996; Man and Kaiser 2001; Toroser et al. 1998).

We have analyzed here the effect of AICAR and related molecules on the expression of fixN, fixT, fixK, and nifA in $S$. meliloti. We demonstrate the modulation of AICAR response by a flavoprotein oxidoreductase encoded by the fix $M$ gene. The possible mode of action of AICAR as well as its physiological significance are discussed.

\section{RESULTS}

AICAR inhibits respiratory and nitrogen fixation gene expression only in specific mutant backgrounds.

Following the demonstration by Soberón and associates (2001) that AICAR inhibited fixN expression, we investigated the effect of AICAR on fixN, fixK, fixT, and nifA expression in different genetic backgrounds, using translational lacZ fusions. We found that a gene of unknown function, fixM, (formerly called orf151 in Batut et al. 1989) located between fix $K_{1}$ and fixN $N_{1}$ (Fig. 1) was involved in AICAR response.

Expression of fixN, fixK, fixT, and nifA was reduced by 9-, 5-, 4-, and 1.7-fold, respectively, when AICAR (0.2 mM) was added to the culture medium of a fixM mutant strain (GMI461) (Fig. 2A, B, C, and D). In contrast, AICAR had no effect on the expression level of an $S$. meliloti hemA control gene fusion (data not shown).

In the GMI5595 strain that was used by Soberón and associates (2001) in their studies, AICAR led to a fivefold repression 
of fixN expression, as expected (Fig. 2E). By contrast, in the wild-type strain (GMI51), AICAR repressed slightly fixN and fixK expression and had no effect on the expression of fix $T$ and nifA (Fig. 2A, B, C, D). Therefore, the deletion carried by the GMI5595 strain (Fig. 1), which removes $16 \mathrm{~kb}$ of fix genes (Renalier et al. 1987), potentiates the effect of AICAR.

In summary, AICAR had little effect on niflfix gene expression in a wild-type strain, whereas it induced a clear repression of fixN, fixT, fixK, and nifA in two mutant backgrounds: GMI5595 and the fixM mutant (GMI461). Further experiments performed in a GMI5595 strain mutated for the fixM gene (double mutant, GMI5602) showed that the effect of AICAR on fixN expression was not enhanced in this strain as compared with the GMI5595 strain (Fig. 2E).

\section{AICAR and 5'AMP have similar effects.}

AICAR is an intermediate in the purine biosynthetic pathway. Therefore, we tested whether other purine-related molecules had an effect similar to that of AICAR (Table 1). Adenosine and AICA-riboside reduced fixN expression by half in a wild-type strain and by ninefold in the fixM mutant strain. In contrast, inosine, guanosine, and their phosphorylated derivatives IMP, GMP, GDP, and GTP had no effect on fixN expression in either background. No effect was registered with the cyclic nucleotides cAMP, cGMP, and cAICAR or with the AICAR-related molecule AICA. 5'AMP, a structural and functional analogue of AICAR (Corton et al. 1995), had an effect similar to that of AICAR, whereas no effect was registered with either $2^{\prime}$ or $3^{\prime}$ AMP or with the di-phosphorylated or the tri-phosphorylated forms. Hence, the active molecule in vivo could be either AICAR or 5'AMP.

Two fixM-like genes in S. meliloti: one is a pseudogene, the other one does not prevent AICAR effect.

Analysis of the genome sequence revealed the presence of two fixM-like genes in S. meliloti. Both are located on the symbiotic pSymA megaplasmid (Fig. 1). One fixM-like gene is located in the reiterated fix cluster that is deleted in the GMI5595 strain. However, this gene presents a STOP codon 12 amino acids (aa) downstream of the predicted start codon and two frameshifts in the open reading frame, suggesting that this orf is not functional. We did not detect transcription of this gene by reverse transcriptase polymerase chain reaction (RTPCR) analysis. These pieces of evidence strongly suggest that this fixM-like gene is a pseudogene.

The second fixM-like gene, SMa1151, is located $34 \mathrm{~kb}$ downstream of fixM. fixM and SMa1151 gene products share $60 \%$ aa identity. As for the fixM gene (discussed below), RTPCR analysis revealed that SMa1151 was transcribed in the bacteroid and in free-living bacteria under oxygen limitation (data not shown). We assayed the $\beta$-galactosidase activity of the translational fixN $N_{1}$-lacZ fusion in a single $S M a 1151$ mutant strain (GMI11260) and in a double SMa1151-fixM mutant strain (GMI11257) in the presence of AICAR $(0.2 \mathrm{mM})$. AICAR did not affect fixN expression in the single SMa1151 mutant strain and the effect of AICAR was not enhanced in the SMa1151-fixM double mutant strain as compared with the single fixM mutant strain (data not shown). Therefore, SMa1151 is not involved in the repression of fixN, fixT, fixK, and nifA by AICAR in S. meliloti.

\section{Regulation of fixM gene expression.}

RT-PCRs were performed on $S$. meliloti RNAs isolated from microoxic free-living bacteria, from oxic free-living bacteria, and from bacteroids isolated 3 weeks after alfalfa inoculation by wild-type $S$. meliloti (GMI211). RT-PCRs were performed with specific primers synthesized from the fixM sequence (Orf151 $1_{1}$ Orf $151_{2}$ ). A fixM transcript was detected in symbiotic bacteroids and in microoxic free-living bacteria (Fig. 3A), whereas it was not detected in a fixJ mutant or in free-living oxic bacteria (Fig. 3B). This indicates that fixM expression is under oxygen and

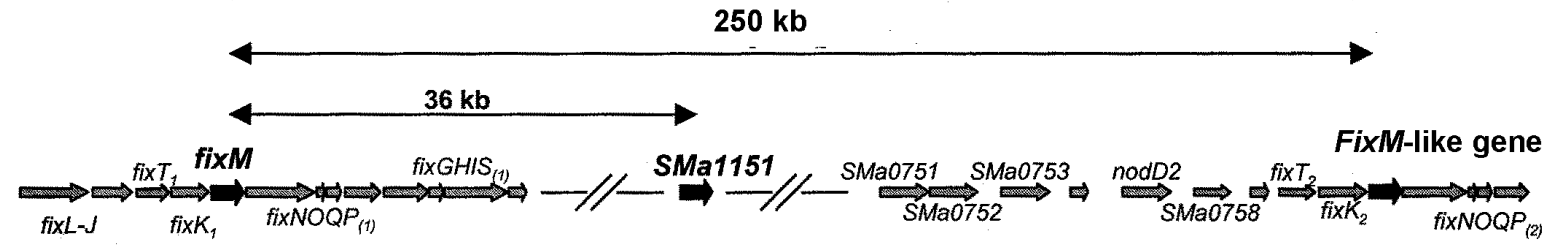

$\longleftarrow 16 \mathrm{~kb}$ deleted region in GMI5595

Fig. 1. fix Genes organization on Sinorhizobium meliloti pSymA megaplasmid.
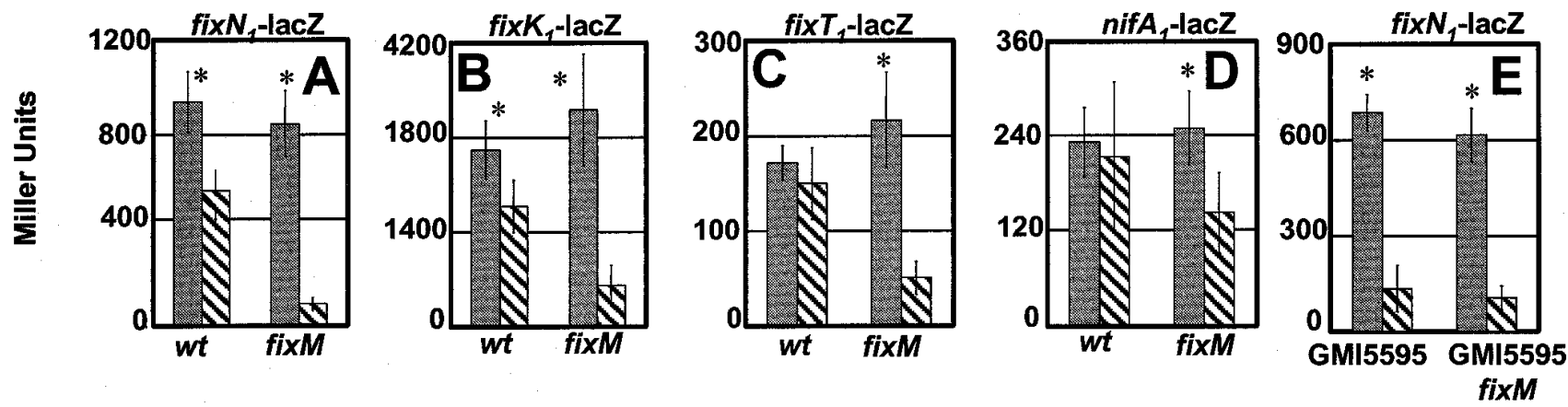

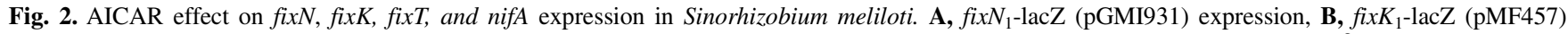
expression, C, fixT $T_{1}$-lacZ (pGD106) expression, D, nifA-lacZ (pCHK57) expression, and E, fixN $N_{1}$-lacZ (pGMI931) expression. The $\beta$-galactosidase assays were performed in the GMI51 (wt) and in the GMI461 (fixM) in the absence of (gray) or the presence of (hatched) AICAR (0.2 mM) under microaerobic conditions. Data are means of four to ten experiments. Standard deviations are indicated. Stars indicate that data in the presence of and the absence of AICAR are statistically different $(P<0.01)$. 
fixJ control. Northern blot experiments indicated that fixM expression was abolished in a fix $K_{1}-$ fix $K_{2}$ double mutant (GMI942) (data not shown). It remains to be demonstrated whether this is due to a cotranscription of fix $K_{1}$ and fixM or whether FixK activates fixM expression at its own promoter.

\section{Symbiotic phenotype of a fixM mutant.}

The disruption of fixM by insertion 2.37 previously was reported not to affect nodulation or nitrogen fixation efficiency during the symbiotic association between S. meliloti and Medicago sativa (Batut et al. 1989). We further analyzed the level of fixN and fixK expression in fixM bacteroids as compared with the level of expression in wild-type bacteroids extracted 5 weeks after alfalfa inoculation. Data showed that fixN expression was slightly repressed in fixM bacteroids as compared with expression in the wild-type strain (Fig. 4A), whereas fixK expression remained unaffected (Fig. 4B). Hence, fixM has no or little effect in symbiosis under standard laboratory conditions.

In further experiments, we engineered a purine biosynthesis mutant (GMI11256) by insertion of a gentamycine resistance cassette in the purH gene. The product of purH metabolizes AICAR into FAICAR; therefore, a $p u r H$ mutant was expected

Table 1. Repressed fixN expression in a fixM mutant strain ${ }^{\mathrm{a}}$

\begin{tabular}{lcc}
\hline Purine metabolites & Wt & fix $\boldsymbol{M}$ \\
\hline AICAR & $61 \pm 10$ & $11 \pm 4$ \\
AICA-riboside & $51 \pm 12$ & $11 \pm 6$ \\
Inosine & $117 \pm 35$ & $130 \pm 50$ \\
Guanosine & $115 \pm 10$ & $121 \pm 11$ \\
Adenosine & $47 \pm 16$ & $11 \pm 2.4$ \\
5'AMP & $32 \pm 5$ & $15 \pm 3$ \\
5'GMP & $117 \pm 3$ & $102 \pm 20$ \\
5'IMP & $102 \pm 10$ & $104 \pm 11$ \\
ADP & $96 \pm 1$ & $141 \pm 56$ \\
GDP & $85 \pm 20$ & $101 \pm 16$ \\
ZDP & $99 \pm 1$ & $143 \pm 13$ \\
ATP & $94 \pm 22$ & $80 \pm 36$ \\
GTP & $94 \pm 30$ & $70 \pm 10$ \\
cAMP & $87 \pm 1$ & $99 \pm 12$ \\
cGMP & $87 \pm 1$ & $87 \pm 5$ \\
cAICAR & $100 \pm 13$ & $92 \pm 15$ \\
AICA & $111 \pm 20$ & $97 \pm 14$ \\
Mixed isomer of 3'AMP and 2'AMP & $109 \pm 20$ & $96 \pm 21$ \\
\hline
\end{tabular}

a $5^{\prime}$ AMP, AICAR, and their nucleoside precursors repress fixN expression in a fixM mutant strain. Exogenous purine metabolites $(0.2 \mathrm{mM})$ were added to wild-type (Wt) Sinorhizobium meliloti strain (GMI51) or to a fixM mutant strain (GMI461) culture medium. Cells were incubated for $3 \mathrm{~h}$ in oxic conditions before starting microaerobic induction. The $\beta$ galactosidase activity of fix $N_{1}$-lacZ in the presence of each metabolite is expressed in percentage of the activity in the absence of added product. to endogenously accumulate AICAR. We assayed the $\beta$-galactosidase activity of the translational fix $K_{1}$-lacZ fusion on 5week-old bacteroids of a single purH mutant (GMI11256) and of a double purH-fixM mutant (GMI11255). Results (Fig. 4B) showed that, when the purH mutation was associated with the fixM mutation, fixK expression was repressed 12-fold compared with the expression in a single purH mutant. However, we were unable to demonstrate AICAR accumulation in the purH mutant using the colorimetric assay of Bratton and Marshall (1939): AICAR concentration in the purH mutant and the wild-type strain were both very low (data not shown). Furthermore, the $S$. meliloti purH mutant was prototrophic for purines, indicating that an unknown salvage pathway synthesizes purines from AICAR or another intermediate upstream of AICAR in the purine pathway. Hence, AICAR accumulation in the purH mutant is not established. In conclusion, whereas the present data solidify the link between purine biosynthesis and fixK gene expression (Soberón et al. 2001), they do not establish that AICAR is the actual effector molecule.

To our surprise, the double fixM-purH mutant was $\mathrm{Fix}^{+}$in symbiosis with $M$. sativa, in spite of the marked decrease of fix $K$ expression. This clearly indicates that fix $K$ expression was not limiting for nitrogen fixation in our assay.

\section{Molecular target for AICAR.}

FixK belongs to the Crp family of regulatory proteins (Batut et al. 1989) and Crp binds the purine-related cAMP effector (Spiro et al. 1990); therefore, we hypothesized initially that AICAR may affect fixN expression by modulating FixK transcriptional activity. In order to directly test this hypothesis, we

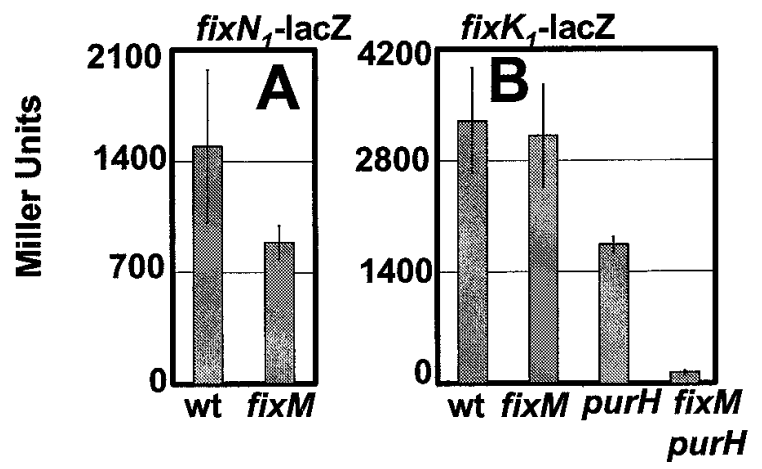

Fig. 4. Endogenously accumulated AICAR affects fixK symbiotic expression. A, fixN $N_{1}$-lacZ (pGMI931) expression in bacteroids. B, fix $K_{1}$ lacZ (pMF457) expression in bacteroids. Data are the mean of four to ten experiments. Standard deviations are indicated.
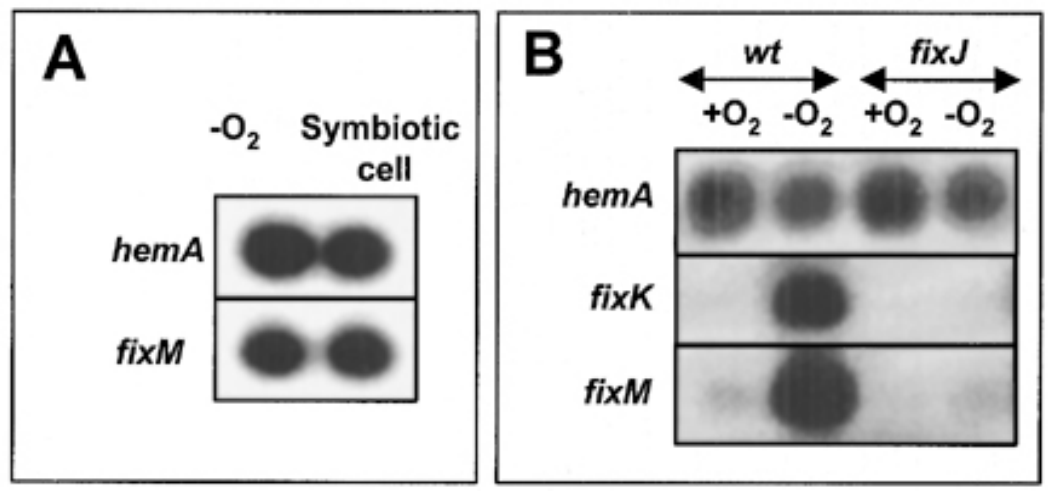

Fig. 3. Reverse transcriptase polymerase chain reaction (RT-PCR) analysis of fixM gene expression. A, RT-PCRs of RNAs isolated from free-living microoxic wild-type strain (GMI211) and from symbiotic bacteroids 3 weeks after alfalfa inoculation. B, RT-PCRs of RNAs isolated from free-living wildtype strain and fixJ mutant strain (GMI347) under microoxic or oxic conditions. 
assayed the effect of AICAR on fixN expression in a strain in which fix $K_{1}$ was expressed under the control of a constitutive promoter. We introduced the plasmid in the wild-type strain (GMI51) and in the fixM mutant strain (GMI461) and assayed AICAR effect on the activity of a fixN $N_{1}$-lacZ fusion in these strains. As shown in Figure 5, fixN expression was not affected anymore by AICAR when fix $K_{1}$ was constitutively expressed. Assays performed in oxic conditions ( $f i x N$ expression does not depend anymore on oxygen in this fix $K^{\mathrm{c}}$ strain) confirmed these results (data not shown). Hence, AICAR does not affect FixK protein activity. Instead, AICAR modifies fixK and nifA expression, by affecting an undetermined target above of fixK and nifA, possibly FixL-J (discussed below). Inactivation of the two copies of fixT in a fixM background (GMI11266) did not affect AICAR effect, thus indicating that FixT does not mediate AICAR effect (data not shown).

\section{fixM encodes a flavoprotein oxydo-reductase.}

We purified the protein encoded by the fixM gene as a fusion with intein (discussed below). The protein was yellow throughout all purification steps, suggesting the presence of a

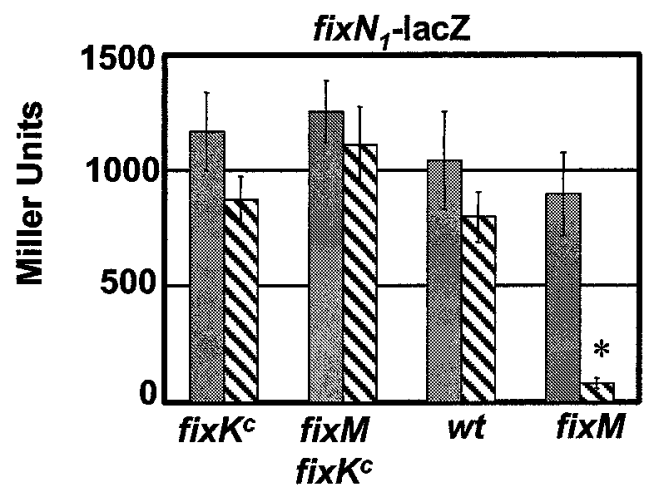

Fig. 5. AICAR did not affect fixN expression when fix $K_{1}$ was constitutively expressed. Expression of fixN (pGMI931) in the indicated genetic backgrounds in the absence of (gray) or the presence of (hatched) AICAR $(0.2 \mathrm{mM})$ under microaerobic conditions. Data are the mean of four to ten experiments. Standard deviations are indicated. Stars indicate that data in the presence of and the absence of AICAR are statistically different $(P<0.01)$. chromophore copurifying with the FixM protein. Visible absorption spectra revealed an absorption maximum at $445 \mathrm{~nm}$ that bleached upon reduction with sodium dithionite under anaerobic conditions (Fig. 6A). These results were suggestive of a flavin prosthetic group. After denaturation in a $1 \%$ sodium dodecyl sulfate (SDS) solution and migration on a PD-10 column (Sephadex G25M; Amersham Pharmacia, Orsay, France), we separated the protein from its yellow prosthetic group, indicating that the FixM apoprotein and its chromophore were not covalently bound. Further separation analyses of the supernatant solution by thin-layer chromatography (TLC) identified a predominant fluorescent species with an $\mathrm{Rf}$ characteristic of flavin adenine dinucleotide (FAD) (Fig. 6B). The characteristic absorbance at $445 \mathrm{~nm}$ and the direct identification of the FAD cofactor showed that FixM is a flavoprotein.

Sequence comparison of the FixM apoprotein with proteins from the NCBI database revealed that FixM is homologous to Nim proteins of Bacteroides fragilis (Trinh and Reysset 1997), sharing $28 \%$ identity at the amino acid level with NimD (Fig. 7). Further FixM homologues have been identified in recently sequenced genomes. Four homologues (BAB52857, BAB52932, BAB54825, and BAB51313) exist in Mezorhizobium loti (Kaneko et al. 2000). The strongest hit reaches $51 \%$ identity at the amino acid level with BAB52857. Another homologue has been detected in the genome of Methanobacterium thermoautotrophicum (Smith et al. 1997) with an identity of $29 \%$ with the FixM protein. The alignment performed with the Multalin and ESPript programs (Corpet 1988; Gouet et al. 1999) shows that these proteins, despite the relatively low level of sequence similarity, present several conserved residues at different positions, indicating that they are indeed homologous (Fig. 7). Nim proteins are the only proteins of this family that have been characterized. They are involved in resistance of $B$. fragilis to 5-nitroimidazole drugs upon reduction on this substrate to 5-aminoimidazoles (Carlier et al. 1997; Townson et al. 1994). We thus conclude that FixM is a flavoprotein oxidoreductase.

\section{DISCUSSION}

We report here that the purine intermediate AICAR represses expression of fixN, fixK, fixT, and nifA in $S$. meliloti in
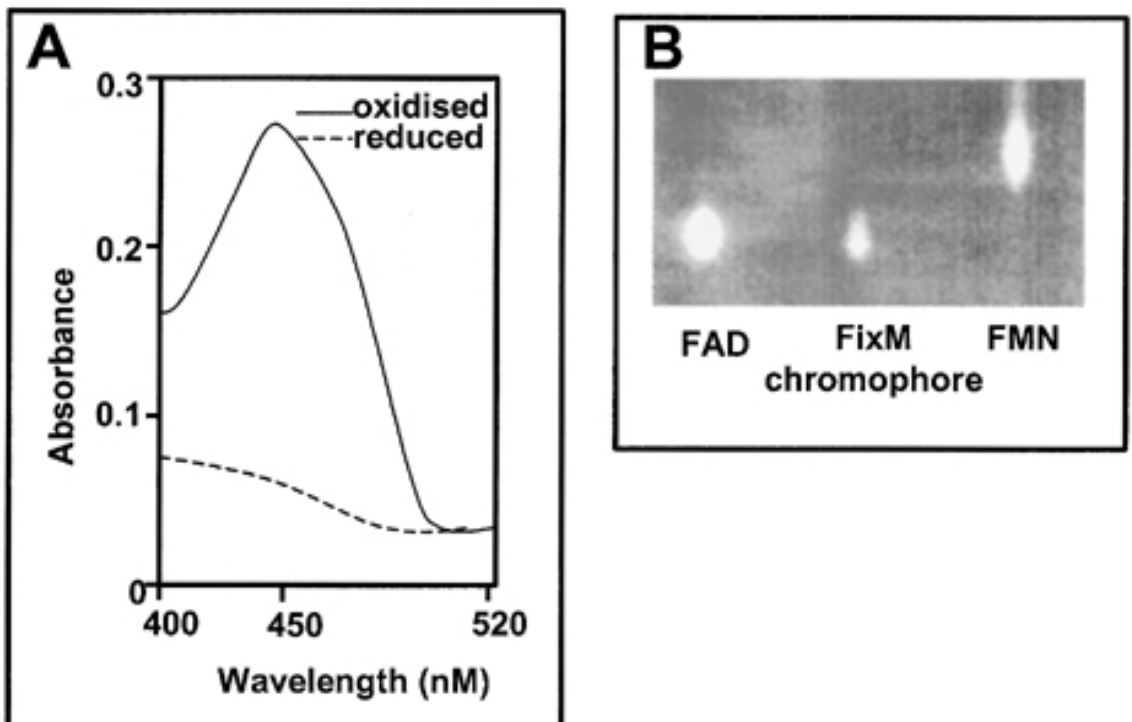

Fig. 6. fixM encodes a flavoprotein. A, Absorbance spectra of oxidized and dithionite-reduced FixM. B, Thin-layer chromatography analysis of the FixMassociated chromophore. Proteins were separated from the prosthetic group by denaturation. 
confirmation of the work by Soberón and associates (2001). A surprising finding of this article is that AICAR is not active in a wild-type strain. Instead, AICAR is active in a fixM mutant strain and in the GMI5595 deleted strain used by Soberón and associates (2001), although we observed a mean repression (fivefold) weaker than that reported by Soberón and associates (2001) (14-fold). We do not know the reason for this difference. Note, however, that GMI5595 and GMI461 are not strictly isogenic (Table 2). The fact that there is little or no effect of AICAR in a wild-type strain, whereas there is an effect in the 16-kb-deleted strain, suggests that a gene missing in GMI5595 mediates inhibition by AICAR. This cannot be the fixM-like gene located in this region, because it is likely a pseudogene. In the GMI5595 background, the AICAR effect is not increased upon fixM inactivation. Therefore, fixM and the gene missing in GMI5595 that modulates the AICAR effect likely belong to the same pathway rather than to alternate pathways. In the deleted region (Fig. 1), four genes encode putative oxydo-reductases (SMa0751, SMa0752, SMa0753, and $S M a 0758$ ). The products of these genes are good candidates to work together with FixM on the reduction of the AICAR substrate.

FixM, together with Nim proteins and unknown hypothetical proteins found in genome databases, forms a new protein family. Nim proteins exert a reductase activity on 5-nitroimidazole rings but were not known to be flavoproteins (Carlier et al. 1997). We showed here that fixM encodes a flavoprotein and suggest that the proteins belonging to this family are all flavoprotein oxidoreductases. The homology of FixM and Nim proteins together with the presence of an imidazole ring in AICAR and 5'AMP suggest that AICAR or 5'AMP is the actual substrate of the FixM reductase. In most flavoproteins described so far, a classical " $\beta \alpha \beta$ " dinucleotide-binding motif known as the Rossman fold, ensures dinucleotide binding (Rossmann et al. 1974). The proteins that adopt a Rossman fold share a consensus sequence referred to as the dinucleotide binding motif (Möller and Amons 1985; Wierenga et al. 1986).
Further conserved motifs involved in dinucleotide interaction have also been described, such as the "GD motif" (Eggink et al. 1990), the "GG motif," and the "ATG motif" (Vallon 2000). Analysis of the FixM amino acid sequence and of its homologues did not reveal any of the above-described signatures. Therefore, this new family of proteins may bind its flavinic prosthetic group in a different way than up-to-now-characterized flavoproteins.

Whether AICAR or a closely related metabolite is the real effector of niflfix gene repression remains to be determined. In this work, we tested different purine-related molecules and showed that $5^{\prime}$ AMP, which is a structural analogue of AICAR, had a similar action to AICAR. In addition, the nucleoside precursor adenosine also repressed fixN expression in a fixM mutant strain. This last result conflicts with that of Soberón and associates (2001), who reported that fix $_{1}-l a c Z$ expression was not affected by adenosine in the GMI5595 strain. Nucleotides are dephosphorylated by periplasmic nucleotidases before being transported into the cell under their nucleoside form (Zalkin and Nygaard 1996). Therefore, it might not be surprising that the effect observed with AICAR and 5'AMP also was observed with their nucleoside precursors. SMc04018, a predicted periplasmic $5^{\prime}$-nucleotidase, is a good candidate for the dephosphorylation of AICAR and 5'AMP before these metabolites enter the cell. SMc04018 is predicted to be specific for $5^{\prime}$ nucleotides and no other candidate for periplasmic nucleotidase has been detected in the $S$. meliloti genome. Consequently, we cannot rule out that $2^{\prime}$ and $3^{\prime}$ AMP were inactive in our assays because they could not enter the cell. As did Soberón and associates (2001), we observed that it was necessary to incubate AICAR for at least $1 \mathrm{~h}$ in oxic conditions to see a repression of fixN expression. This might correspond to the time needed for these metabolites to be transported into the cell.

Experiments performed in a strain in which fix $K$ was constitutively expressed showed that AICAR lost its effect when fixK expression was not controlled by the FixLJ regulatory system. We thus speculate that AICAR may target the FixLJ
SMa1.2.3

SMa1151

MLA-BA52857

Bf $-n i m$

ats-669012

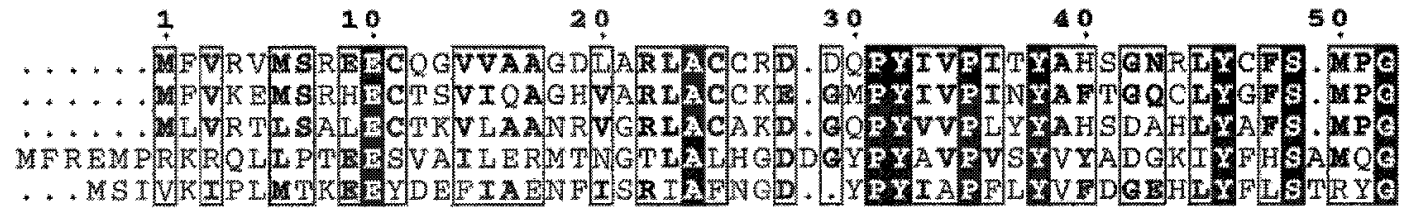

60

70

80

90

100

129

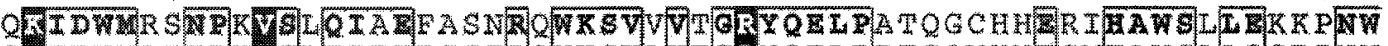

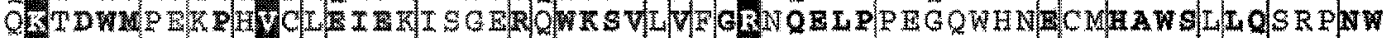

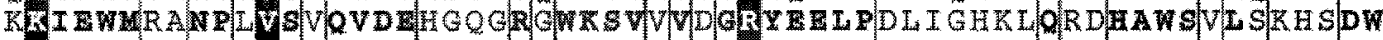

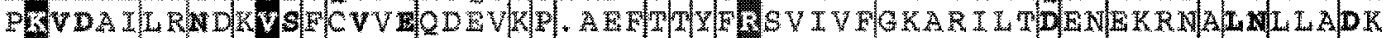

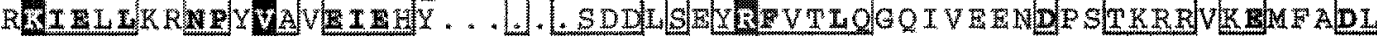

stan 1151

M. $-5 A B 5287$

BI-nino

LEth-669012 
two-component system (Fig. 8). However, present attempts to evidence an AICAR or 5'AMP effect in vitro on purified FixLJ proteins remain so far inconclusive. FixL autophosphorylation, FixJ phosphorylation by FixL, FixJ transcriptional activity, FixJ dimerization, and DNA binding at the fix $K$ promoter were unaffected by AICAR in vitro (data not shown). Several possibilities may account for this observation. First, it is not certain that AICAR or 5'AMP is the actual effective molecule in vivo. Second, AICAR could alter the intracellular levels of ATP, ADP, or AMP and thereby indirectly affect the activity of the FixL kinase in vivo. Third, the AICAR effect may require a third protein yet to be identified. In plants, AICAR and 5'AMP alike regulate phosphorylated proteins through the interaction with 14-3-3 proteins (Athwal et al. 2000; Finnemann and Schjoerring 2000; Kaiser and Huber 2001; Toroser et al. 1998). The common theme in 14-3-3 proteins action is their ability to associate with phosphorylated target proteins (Bachmann et al. 1996; Moorhead et al. 1999; Tzivion and Avruch, in press). However, 14-3-3 proteins have not been reported so far in any prokaryotic organism including $S$. meliloti.

The physiological significance of the regulation of nitrogen fixation and respiration by AICAR, 5'AMP, or a derived metabolite and the related issue of the biological role of fixM remain open questions. The present data, as well as former data (Soberón et al. 1997, 2001), suggest a regulatory link between purine biosynthesis and nitrogen fixation gene expression in $S$. meliloti. Although the possible physiological significance of this link remains unclear, it should be remembered here that, on the plant side, fixed nitrogen (ammonia) assimilation and de novo purine biosynthesis are closely linked in tropical legumes (Schubert 1986).
Another clear hint we can offer in the context of symbiosis is the well-documented accumulation of 5'AMP in anoxiated pea roots (Glaab and Kaiser 1993) or otherwise environmentally stressed cells (Corton et al. 1994). Nodule plant cells undergo a profound anoxia (less than $30 \mathrm{nM}$ free $\mathrm{O}_{2}$ ); therefore, it is possible, although not established to our knowledge, that nodule plant cells accumulate AICAR or 5'AMP. Plant-generated $5^{\prime}$ AMP or AICAR may, in turn, inhibit bacteroid gene expression. Alternatively, AICAR or 5'AMP could be generated in bacteroids themselves upon stress induction. In both cases, the function of the FixM protein would be to turn over 5'AMP or AICAR and convert it, together with additional enzymes, into a form that is no longer inhibitory on gene expression. The close physical link between fixM and fixLJT $K_{1}$ (Fig. 7) as well as fixM gene expression under free-living microoxic and symbiotic conditions suggest that fix $M$ function is genuinely related to respiration and nitrogen fixation. Nevertheless, a fixM mutant is essentially unaffected for symbiotic properties, at least under the laboratory conditions we used, hence suggesting that AICAR or 5'AMP normally does not accumulate to inhibitory levels. However, there is the possibility of AICAR or 5'AMP bursts in the nodule under stressful conditions (extreme anoxia, carbon shortage, and so on) or at specific moments during nodule differentiation, as during infection, as suggested before by Soberón and associates (2001). Hence, AICAR or 5'AMP might act as a signal molecule that finely tunes down respiration, energy production, and nitrogen fixation by the microsymbiont under inappropriate physiological conditions. We also cannot rule out the possibility of other enzymes contributing, independently of

Table 2. Main bacterial strains and plasmids used in this study

\begin{tabular}{|c|c|c|}
\hline Strain or plasmid & Relevant characteristics & Reference \\
\hline \multicolumn{3}{|l|}{ Escherichia coli } \\
\hline $\mathrm{DH} 5 \alpha$ & EndA1, gyrSA96, hrd17(rK-mK-), supE44, recA1 & Boyer and Roulland-Dussoix 1969 \\
\hline ER2566 & 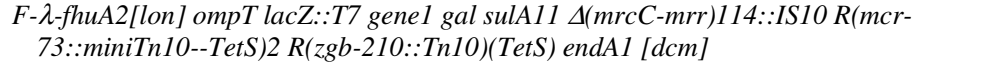 & New England Biolabs \\
\hline \multicolumn{3}{|c|}{ Sinorhizobium meliloti } \\
\hline GMI51 & Wild-type strain, $\mathrm{Nod}^{+}, \mathrm{fix}^{+}$ & Rosenberg et al. 1981 \\
\hline GMI211 & GMI51 derivative, $\mathrm{lac}^{-}, \mathrm{Sm}^{\mathrm{r}}, \mathrm{Nod}^{+}, \mathrm{Fix}^{+}$ & Niel et al. 1977 \\
\hline GMI461 & Disruption of fixM by insertion 2.37 in GMI51- $\mathrm{Sm}^{\mathrm{r}}, \mathrm{Nm}^{\mathrm{r}}, \mathrm{Bleo}^{\mathrm{r}}, \mathrm{Nod}^{+}, \mathrm{Fix}^{+}$ & Batut et al. 1989 \\
\hline GMI347 & Disruption of fixJ by insertion 2.3 in GMI51- $\mathrm{Sm}^{\mathrm{r}}, \mathrm{Nm}^{\mathrm{r}}, \mathrm{Bleo}^{\mathrm{r}}, \mathrm{Nod}^{+}, \mathrm{Fix}^{-}$ & Batut et al 1985 \\
\hline GMI942 & Disruption of fixK ${ }_{1}$ by insertion of a $\Omega$ cassette in GMI940- Nod $^{+} \mathrm{Fix}^{-}$ & Foussard et al. 1997 \\
\hline GMI11260 & Disruption of SMa1151 by insertion of a $\Omega$ cassette in GMI51- $\mathrm{Spec}^{\mathrm{r}}, \mathrm{Nod}^{+}, \mathrm{Fix}^{+}$ & This study \\
\hline GMI11257 & $\begin{array}{l}\text { Disruption of SMa1151 by insertion of a } \Omega \text { cassette in GMI461- } \mathrm{Sm}^{\mathrm{r}}, \mathrm{Nm}^{\mathrm{r}}, \mathrm{Bleo}^{\mathrm{r}}, \mathrm{Spec}^{\mathrm{r}} \text {, } \\
\mathrm{Nod}^{+}, \mathrm{FiX}^{\mathrm{r}}\end{array}$ & This study \\
\hline GMI11256 & Disruption of purH by insertion of a $\Omega$ cassette in GMI51- $\mathrm{Gm}^{\mathrm{r}}, \mathrm{Nod}^{+}, \mathrm{Fix}^{+}$ & This study \\
\hline GMI11255 & $\begin{array}{l}\text { Disruption of purH by insertion of a } \Omega \text { cassette in the GMI } 461-\mathrm{Sm}^{\mathrm{r}}, \mathrm{Nm}^{\mathrm{r}}, \mathrm{Bleo}^{\mathrm{r}}, \mathrm{Gm}^{\mathrm{r}} \text {, } \\
\mathrm{Nod}^{+}, \mathrm{Fix}^{+}\end{array}$ & This study \\
\hline GMI708 & Rif $^{\mathrm{r}}, \mathrm{Nod}^{+}, \mathrm{Fix}^{+}$ & Batut et al. 1985 \\
\hline GMI5595 & 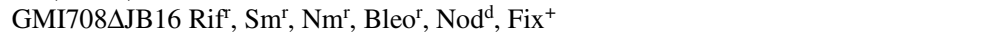 & Renalier et al. 1987 \\
\hline GMI5602 & $\begin{array}{l}\text { Transduction of the } 2.37 \text { Tn5 insertion in fixM from GMI461 to GMI5595- } \text { Rif }^{\mathrm{r}}, \mathrm{Sm}^{\mathrm{r}} \text {, } \\
\mathrm{Nm}^{\mathrm{r}}, \mathrm{Bleo}^{\mathrm{r}}, \mathrm{Nod}^{\mathrm{d}}, \mathrm{Fix}^{+}\end{array}$ & Batut et al. 1989 \\
\hline GMI882 & Disruption of fix $K_{1}$ by insertion 2.81 in GMI51- $\mathrm{Nm}^{\mathrm{r}}, \mathrm{Bleo}^{\mathrm{r}}, \mathrm{Nod}^{+}, \mathrm{Fix}^{+}$ & Batut et al. 1989 \\
\hline GMI11266 & Insertion of the fixT $T_{1}$ mutation in GMI5602 strain $\mathrm{Rif}^{\mathrm{r}}, \mathrm{Sm}^{\mathrm{r}}, \mathrm{Nm}^{\mathrm{r}}$, Bleo ${ }^{\mathrm{r}}$ & This study \\
\hline \multicolumn{3}{|c|}{ - } \\
\hline pUC0441 & $\begin{array}{l}\text { pUC19 containing fixM used as a marker to generate a high density map of } S \text {. meliloti } \\
\text { genome- } \mathrm{Ap}^{\mathrm{r}}\end{array}$ & Barloy-Hubler et al. 2000 \\
\hline pJQ200KS & Suicide vector used for site directed mutagenesis in $S$. meliloti- $\mathrm{Gm}^{\mathrm{r}}$ & Quandt et al. 1993 \\
\hline pNPTS139 & Suicide vector used for site directed mutagenesis in $S$. meliloti- $\mathrm{Km}^{\mathrm{r}}$ & Tsai et al. 2001 \\
\hline pGMI931 & pIJ363 derivative carries fix $N_{1}-$ lacZ fusion $-\mathrm{Tc}^{\mathrm{r}}$ & David et al. 1987 \\
\hline pMF457 & pGD926 derivative, carries a fix $K_{1}$-lacZ fusion and a mutation in fix $T_{1}$ promoter- $\mathrm{Tc}^{\mathrm{r}}$ & Foussard et al. 1997 \\
\hline pGD106 & pGD926 derivative, carries a fix $T_{1}$-lacZ fusion $-\mathrm{Tc}^{\mathrm{r}}$ & Foussard et al. 1997 \\
\hline pCHK57 & pGD926 derivative, carries a nifA-lacZ fusion- $-\mathrm{Tc}^{\mathrm{r}}$ & Ditta et al. 1987 \\
\hline pML123 & IncQ broad host range vector- $\mathrm{Gm}^{\mathrm{r}}$ & Labes et al. 1990 \\
\hline pML123-fix $K_{1}$ & pML123 derivative, carries fix $K_{1}-\mathrm{Gm}^{\mathrm{r}}$ & This study \\
\hline $\mathrm{pHP} 45(\Omega)$ & pBR322 derivative carries the spectinomycine resistance $\Omega$ cassette & Prentki and Krisch 1984 \\
\hline pTYB-fixM & $\mathrm{PTYB}_{2}$ derivative, carries the fixM-inteine fusion- $\mathrm{Ap}^{\mathrm{r}}$ & This study \\
\hline $\mathrm{pKS}+457$ & pBluescript-II KS+ derivative carrying the fix $T_{1}$ mutation & Foussard et al 1997 \\
\hline pUC1318 & PUC19 derivatives carries the gentamycine resistance cassette- $\mathrm{Ap}^{\mathrm{r}}$ & Brau et al. 1984 \\
\hline
\end{tabular}


fixM, to AICAR or 5'AMP detoxification, which would explain why inactivation of the sole fixM gene has a limited effect on gene expression.

\section{MATERIALS AND METHODS}

Microbiological techniques.

The bacterial strains and plasmids used in this study are listed in Table 2. Escherichia coli strains were grown at $37^{\circ} \mathrm{C}$ in Luria broth (LB) complex medium (Maniatis et al. 1982). $S$. meliloti strains were grown at $30^{\circ} \mathrm{C}$ in tryptone yeast (TY) complex medium (Truchet et al. 1985) or in defined M9 medium (Miller 1972) supplemented with $\mathrm{MgSO}_{4}(1 \mathrm{mM})$, biotin $(2 \mu \mathrm{M})$, and glucose $(20 \mathrm{mM})$. Microoxic conditions were achieved either as described by de Philip and associates (1990) ( $2 \%$ oxygen for $4 \mathrm{~h}$ ) or using the stoppered tube assay (STA) described by Ditta and associates $(1987)(<1 \%$ oxygen for $16 \mathrm{~h})$. Matings were performed between recipient strains, donor strains, and the helper strain K12 (pRK2013), when necessary, as described previously (Truchet et al. 1985). N3 phage transduction was performed as described by Finan and associates (1984).

\section{AICAR assay.}

Purine metabolites were purchased from Sigma (St. Louis) and were all dissolved in water at the final concentration of 15 mM. AICAR (Sigma \#A1393) was neutralized in $60 \mathrm{mM}$ TRIS-HCL, pH 8.3. Strains were grown for $24 \mathrm{~h}$ in TY medium at $30^{\circ} \mathrm{C}$ with agitation $(250 \mathrm{rpm})$. This culture was used to inoculate $15 \mathrm{ml}$ of minimal M9 medium at an optical density at $600 \mathrm{~nm}\left(\mathrm{OD}_{600}\right)$ of 0.05 . The strains then were grown at $30^{\circ} \mathrm{C}$ with agitation to an $\mathrm{OD}_{600}$ of 0.4 . AICAR (or other purine metabolites) then were added at a final concentration of $0.2 \mathrm{mM}$. After an additional $4 \mathrm{~h}$ of aerated growth at $30^{\circ} \mathrm{C}$ in the presence of AICAR, the growth conditions were turned to microoxic for $4 \mathrm{~h}$ to induce fix and nif gene expression. The growth medium $(200 \mu \mathrm{l})$ was pelleted and resuspended in 700 $\mu \mathrm{l}$ of buffer $\mathrm{Z}\left(\mathrm{Na}_{2} \mathrm{HPO}_{4}, 60 \mathrm{mM} ; \mathrm{NaH}_{2} \mathrm{PO}_{4}, 40 \mathrm{mM}\right.$; KCL, 10 $\mathrm{mM} ; \mathrm{MgSO}_{4}, 1 \mathrm{mM}$; $\beta$-mercaptoethanol, $50 \mathrm{mM}$; $\mathrm{pH}$ 7). Cells were permeabilized with $100 \mu \mathrm{l}$ of chloroform and $50 \mu \mathrm{l}$ of SDS, and $\beta$-galactosidase activity was measured as described by Miller (1972). The activity is expressed in nmol of $o$-nitrophenyl- $\beta$-D-galactoside hydrolyzed per minute and per $\mathrm{OD}_{600}$ unit.

\section{Plant tests.}

M. sativa cv. Gemini seedlings were aseptically grown on agar slants made with nitrogen-free Fahraeus medium. Plants (3-day-old) were inoculated with different $S$. meliloti strains. Nodules $(0.25 \mathrm{~g})$ were harvested and were immediately frozen in liquid nitrogen 5 weeks after inoculation. Nodules were ground in liquid nitrogen in alumina powder (A5 type, Sigma) with a mortar and pestle, and the paste was resuspended in 1.6 $\mathrm{ml}$ of the following buffer: $\mathrm{Na}_{2} \mathrm{HPO}_{4}, 60 \mathrm{mM} ; \mathrm{NaH}_{2} \mathrm{PO}_{4}, 40$ $\mathrm{mM}$; $\mathrm{KCl}, 10 \mathrm{mM}$; $\mathrm{MgSO}_{4}, 1 \mathrm{mM}$; mannitol, $0.5 \mathrm{M}$; pH 7. Debris were sedimented by centrifugation for $10 \mathrm{~min}$ at $g \times$ 12,000 . $\beta$-galactosidase activity was assayed on $400 \mu \mathrm{l}$ of supernatant of this extract. The activity is expressed in nmol of $o$-nitrophenyl- $\beta$-D-galactoside hydrolyzed per minute per $\mathrm{mg}$ of proteins. Total protein concentration was determined as described by Bradford (1976). The endogenous $\beta$-galactosidase activity of the plant cell was negligible in our experiments.

\section{RT-PCR analysis.}

RNA extraction and RT-PCR reactions were performed as described by Cabanes and associates (2000a, 2000b). The amplified products were subjected to Southern hybridization with the specific ${ }^{32} \mathrm{P}$-labeled probe generated by PCR on $S$. meliloti total DNA. No RT-PCR product was detected in controls lacking reverse transcriptase during the cDNA synthesis

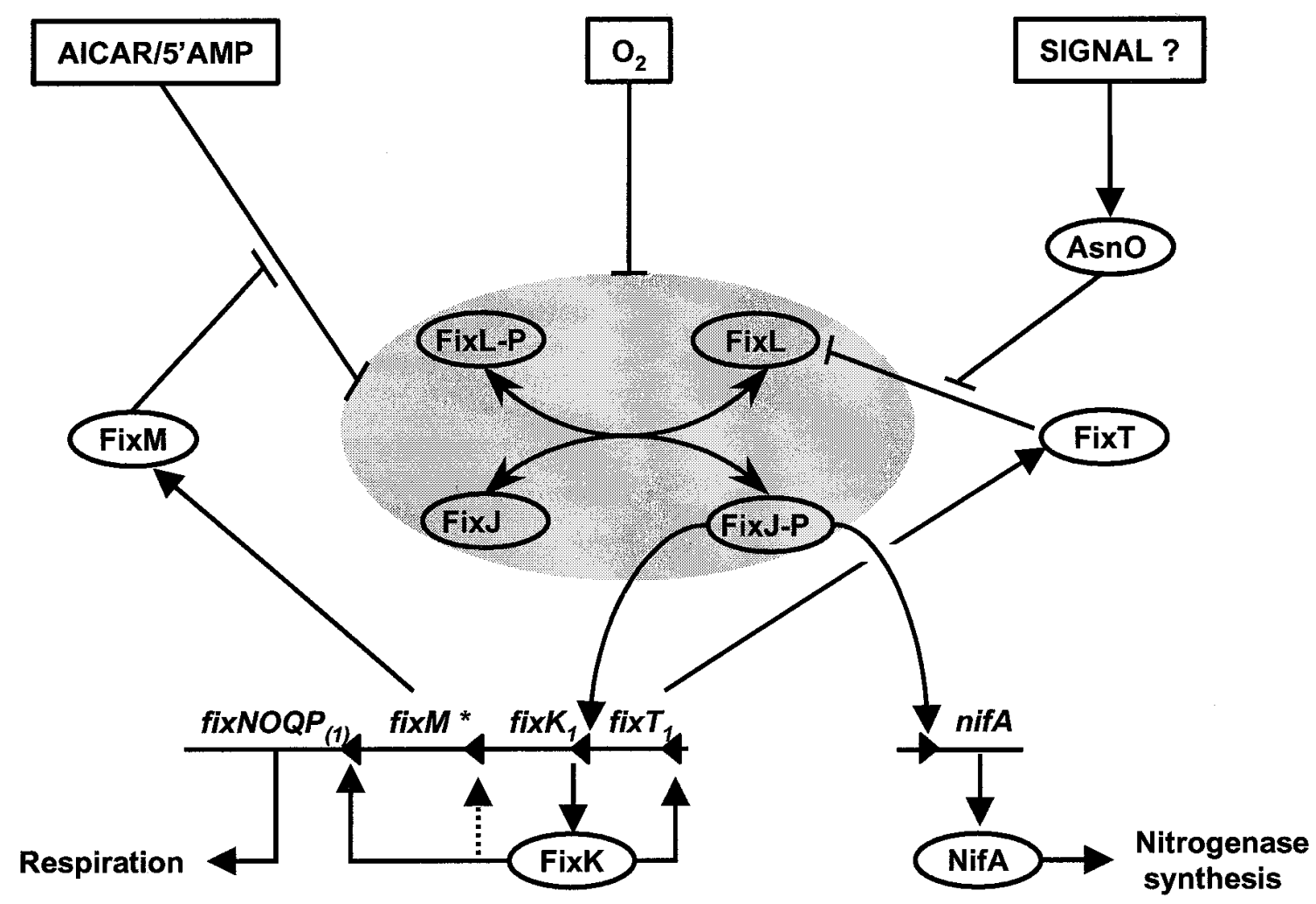

Fig. 8. An updated model for the regulation of nif and fix gene expression br FixLJ in Sinorhizobium meliloti. The dashed arrow indicates the possibility that fixK activates the fixM promoter. * = fixM was annotated as SMa1223 during the $S$. meliloti sequencing project. 
step, thus excluding the presence of DNA contaminating the RNA preparations. As a control of the amount of RNA in the reactions, the $S$. meliloti hemA gene was subjected to RTPCR procedure with hem $\mathrm{A}_{\text {sens }}$-hem $\mathrm{A}_{\text {antisens. }}$ The fixM transcript was detected with orf $151_{1}$-orf $151_{2}$. The SMal151 transcript was detected with orf $151_{10}$-orf $151_{11}$. The fixM-like gene located in the reiterated fix gene cluster was detected with $\mathrm{CD}_{5}-\mathrm{CD}_{9}$ (Table 3).

\section{Construction of mutants.}

The SMa1151 coding region was amplified in two pieces by PCR with two pairs of primers using pUC0441 (Table 2) as a template. The primers M13 and Bam151a generated a 650-bp fragment, and the primers Rev and Bam $151 \mathrm{~b}$ generated a 480-bp fragment. Bam151a and Bam 151 b were designed with a Bam $\mathrm{H} 1$ restriction site at the $5^{\prime}$ end. The 650 bp and the 480-bp fragment were digested with BamH1 and ligated together. The ligated fragment then was digested with Kpn 1 and Pst 1 and cloned in pUC19, generating a new plasmid called pUC0441-BamH1. This plasmid contains the SMa1151 gene with an extra Bam $\mathrm{H} 1$ restriction site in which a $\Omega$ interposon cassette was inserted as a $1.9-\mathrm{kb}$ Bam $\mathrm{H} 1$ DNA fragment extracted from $\mathrm{pHP} 45 \Omega$. A 3-kb Sst $1-P$ st 1 fragment carrying the $\Omega$ interposon inserted in SMa1151 was subsequently cloned in pJQ200KS (Quandt and Hynes 1993). The cassette then was recombined into the indigenous SMa1151 gene of the wild-type strain GMI51, selecting on spectinomycine resistance $\left(100 \mu \mathrm{g} \mathrm{ml} \mathrm{m}^{-1}\right)$ conferred by the cassette and sucrose tolerance (elimination of pJQ200KS vector DNA). When necessary, the mutation was moved to other S. meliloti backgrounds by N3 phage transduction. PCR analyses were performed to ensure the presence of the $\Omega$ interposon at the expected location.

A 1.2-kb purH fragment gene was generated by PCR using purH $_{5}$ and purH $_{16}$ as primers and wild-type $S$. meliloti DNA as template. This fragment was cloned in the PCR product cloning vector pGEM-T (pGEM-T Vector System; Promega, Madison, WI, U.S.A.). A $\Omega$ interposon cassette was inserted as a 1kb DNA fragment extracted from pUC1318 (Brau et al. 1984) into the $E c o \mathrm{R} 1$ site present in the middle of the $\mathrm{purH}$ fragment gene. A 2.2-kb Pst1-Apa 1 fragment carrying $\Omega$ inserted in purH fragment gene subsequently was cloned into the suicide vector pNPTS139 (Tsai and Alley 2001). The cassette then was recombined into the indigenous purH gene of the wildtype $S$. meliloti strain (GMI51), selecting on gentamycine resistance $\left(30 \mu \mathrm{g} \mathrm{ml}^{-1}\right)$ conferred by the cassette and sucrose tolerance (elimination of pNPTS139 vector DNA). When necessary, the mutation was moved to other $S$. meliloti strains by N3 phage transduction. PCR analyses were performed to ensure the presence of the $\Omega$ interposon at the expected location.

An 880-bp DNA fragment containing the entire fix $K_{1}$ gene and its ribosome binding site was amplified by PCR using K$r b s$ and K-hindIII primers and S. meliloti wild-type DNA as template. The amplified fragment was cloned in pGEM-T. Correct orientation was checked by PCR on colonies using fixKr and sp6 as primers. A HindIII-SacI 880-bp fragment containing fix $K_{1}$ subsequently was cloned in pML123, generating the pML123-fix $K_{1}$ plasmid. This plasmid was introduced in a $\mathrm{DH} 5 \alpha$ strain by electroporation and the fix $K_{1}$ insert was checked by sequencing. pML123-fix $K_{1}$ was introduced in $S$. meliloti by triparental mating using gentamycine resistance (30 $\mu \mathrm{g} \mathrm{ml}^{-1}$ ) as a selective marker.

The fixT mutation carried by $\mathrm{pKS}+457$ was introduced into GMI5602 as described by Foussard and associates (1997).

\section{Purification of the FixM protein.}

The fix $M$ coding region was amplified by PCR from genomic DNA using the orf151-NdeI and orf151-SmaI primers. These primers have been designed so that they include an NdeI and Sma1 extra restriction sites that permitted in-frame cloning of fix $M$ in the $\mathrm{pTYB}_{2}$ intein vector (New England Biolabs, Beverly, MA, U.S.A.). The ligated product was electroporated into $E$. coli ER2566, selecting on ampicillin resistance $\left(100 \mu \mathrm{g} \mathrm{ml}^{-1}\right)$. The fixM-Intein insert was entirely sequenced to ensure that no undesired alteration occurred during its construction. The resulting plasmid was named pTYB-fixM. ER2566 cells harboring pTYB-fixM plasmid were grown at $19^{\circ} \mathrm{C}$ in 21 of LB medium supplemented with ampicillin at $100 \mu \mathrm{g} \mathrm{ml}^{-1}$. When $\mathrm{OD}_{600}$ reached a value of 0.6 , IPTG was added to a final concentration of $0.3 \mathrm{mM}$. After an additional $8 \mathrm{~h}$ at $19^{\circ} \mathrm{C}$, four fractions of 500 $\mathrm{ml}$ of cells were separately pelleted. All subsequent steps were performed at $4^{\circ} \mathrm{C}$, essentially as recommended by New England Biolabs. Cells were suspended in $20 \mathrm{ml}$ of buffer S (Tris, 20 $\mathrm{mM}$; EDTA, $1 \mathrm{mM}$; NaCl, $200 \mathrm{mM}$ ) and disrupted by sonica-

Table 3. Primers used in this study

\begin{tabular}{|c|c|c|}
\hline Genes & Name & Sequence \\
\hline \multicolumn{3}{|l|}{ fixM } \\
\hline Forward & orf $151_{1}$ & 5'-CTGCAGATTGCCGAGTTTGCC-3' \\
\hline Reverse & orf $151_{2}$ & 5'-CCCCGTCATCTCGTCCATCTCC-3' \\
\hline Forward & orf151-nde 1 & 5'-GGAATTCCATATGTTCGTGAGGGTAATGTC-3' \\
\hline Reverse & orf151-sma1 & $5^{\prime}$-TCCCCCGGGTAACTCACCCGCGCAGGC-3' \\
\hline \multicolumn{3}{|r|}{ 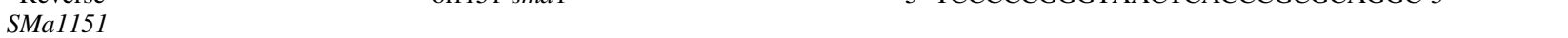 } \\
\hline Forward & bam151a & 5'-CGCGGATCCTCCTGGTAACGG-3' \\
\hline Reverse & bam $151 \mathrm{~b}$ & 5'-GCGGGATCCGCCTGCGGGGC-3' \\
\hline Forward & orf $151_{10}$ & 5'-TACAAGTGTGATTCAGGCAGG-3' \\
\hline Reverse & orf $151_{11}$ & $5^{\prime}$-GCCACTGCCCCTCAGGC-3' \\
\hline \multicolumn{3}{|c|}{ fixM-like gene } \\
\hline Forward & $\mathrm{CD}_{5}$ & $5^{\prime}$-TCTATCGCCGGGCC-3' \\
\hline Reverse & $\mathrm{CD}_{9}$ & $5^{\prime}$-CAGGGACGGCCAGCC-3' \\
\hline \multicolumn{3}{|l|}{ fix $K_{1}$} \\
\hline Forward & fix $_{\mathrm{f}}$ & $5^{\prime}$-ТAT CTA CCG CCT CCT TTC-3' \\
\hline Reverse & fixK $_{r}$ & 5'- GCATCTTCTGGTAATCGG-3' \\
\hline Forward & $\mathrm{K}-r b s$ & 5'-CGAACGGGGAATAATTCATGTACGCCGCTGC-3' \\
\hline Reverse & $\mathrm{K}-h i n d \mathrm{III}$ & 5'-CCCAAGCTTTCAATTGCAAAGCGAGCGCAGCGC-3' \\
\hline \multicolumn{3}{|r|}{ 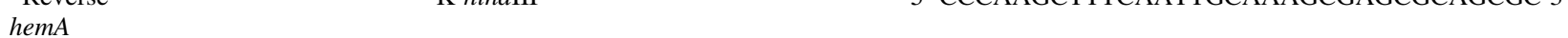 } \\
\hline Forward & hem $A_{\text {sens }}$ & $5^{\prime}$-TGGATGGGCTGCATCA-3' \\
\hline Reverse & hemA $A_{\text {antisens }}$ & 5'-GTGGATCGCGTTCTT-3' \\
\hline \multicolumn{3}{|l|}{ purH } \\
\hline Forward & $\mathrm{PurH}_{5}$ & $5^{\prime}$-ACGATCGTCACCG-3' \\
\hline Reverse & PurH $_{16}$ & 5'-TTCGTCGCGCATCGAACCACCCG-3' \\
\hline
\end{tabular}


tion. The chitin beads column $(50 \mathrm{ml})$ was equilibrated with buffer S (10 volumes) before adding the crude extract. After extensive washing with 10 volumes of buffer $\mathrm{S}$ containing $0.1 \%$ triton and after equilibration with 5 volumes of buffer $\mathrm{S}$, the column was incubated overnight with buffer $S$ containing $50 \mathrm{mM}$ of dithiothreitol. Fractions were collected and screened for the presence of FixM protein by SDS-polyacrylamide gel electrophoresis on a Pharmacia Phast gel system. Fractions containing FixM protein were concentrated with a YM10 centricon (amicon bioseparation, millipore). At this final step, the cleaved FixM concentrated protein appeared yellow and insoluble.

Precipitated FixM was analyzed after solubilization in a buffer containing Tris, $20 \mathrm{mM}$; NaCL, $300 \mathrm{mM}$; EDTA, 1 $\mathrm{mM}$; SDS, $1 \%$. Absorbance spectra were recorded with a Beckman DU 640B spectrophotometer in the presence or absence of $6 \mathrm{mM}$ sodium dithionite. TLC analyses of the FixM chromophore were performed on Kieselgel 60F254 plates (Merck, Strasbourg, France) in parallel with standards of flavin mononucleotide and FAD, in a buffer containing butanol, acetic acid, and water $(12: 3: 5 \mathrm{vol} / \mathrm{vol})$. The spots were visualized under UV light (312 $\mathrm{nM})$.

\section{ACKNOWLEDGMENTS}

We thank M. Soberón (UNAM, Mexico) for drawing our interest to AICAR and for the free exchange of information during the course of this work; R. White for advice on AICAR measurements in vivo; the French Ministère de l'Enseignement Supérieur et de la Recherche for a doctoral fellowship supporting C. Cosseau; and M. Soberón and members of J. Batut's team for critically reading the manuscript. The work was initiated during the course of the EU-funded FIXNET programme (BIO4-CT972319).

\section{LITERATURE CITED}

Athwal, G. S., Lombardo, C. R., Huber, J. L., Masters, S. C., Fu, H., and Huber, S. C. 2000. Modulation of 14-3-3 protein interactions with target polypeptides by physical and metabolic effectors. Plant Cell Physiol. 41:523-533.

Bachmann, M., Huber, J. L., Athwal, G. S., Wu, K., Ferl, R. J., and Huber, S. C. 1996. 14-3-3 proteins associate with the regulatory phosphorylation site of spinach leaf nitrate reductase in an isoform-specific manner and reduce dephosphorylation of Ser- 543 by endogenous protein phosphatases. FEBS (Fed. Eur. Biochem. Soc.) Lett. 398:26-30.

Barloy-Hubler, F., Capela, D., Barnett, M. J., Kalman, S., Federspiel, N A., Long, S. R., and Galibert, F. 2000. High-resolution physical map of the Sinorhizobium meliloti 1021 pSyma megaplasmid. J. Bacteriol. 182:1185-1189.

Batut, J., Daveran-Mingot, M. L., David, M., Jacobs, J., Garnerone, A. M., and Kahn, D. 1989. FixK, a gene homologous with fnr and crp from Escherichia coli, regulates nitrogen fixation genes both positively and negatively in Rhizobium meliloti. EMBO (Eur. Mol. Biol. Organ.) J. $8: 1279-1286$.

Batut, J., Terzaghi, B., Gherardi, M., Huguet, M., Terzaghi, A., Garnerone, A. M., Boistard, P., and Huguet, T. 1985. Localization of a symbiotic fix region on Rhizobium meliloti pSymA megaplasmid more than 200 kilobases from the nod-nif region. Mol. Gen. Genet. 199:232-239.

Berges, H., Checroun, C., Guiral, S., Garnerone, A. M., Boistard, P., and Batut, J. 2001. A glutamine-amidotransferase-like protein modulates FixT anti-kinase activity in Sinorhizobium meliloti. BMC. Microbiology 1:6

Boyer, H.W., and Roulland-Dussoix, D. 1969. A complementation analysis of the restriction and modification of DNA in Escherichia coli. J. Mol. Biol. 41:459-472.

Bradford, M. M. 1976. A rapid and sensitive method for the quantification of microgram of protein utilizing the principle of protein-dye binding. Anal. Biochem. 72:248-254.

Bratton, A. C., and Marshall, J. 1939. A new coupling component for sulfanilamide determination. J. Biol. Chem. 128:537-550.

Brau, B., Pilz, U., and Piepersberg, W. 1984. Genes for gentamicin-(3)-Nacetyltransferases III and IV: I. Nucleotide sequence of the AAC(3)-IV gene and possible involvement of an IS140 element in its expression. Mol. Gen. Genet. 193:179-187.

Cabanes, D., Boistard, P., and Batut, J. 2000a. Identification of Sinorhizobium meliloti genes regulated during symbiosis. J. Bacteriol. 182:3632-3637.
Cabanes, D., Boistard, P., and Batut, J. 2000b. Symbiotic induction of pyruvate dehydrogenase genes from Sinorhizobium meliloti. Mol. PlantMicrobe Interact. 13:483-93.

Carlier, J. P., Sellier, N., Rager, M. N., and Reysset, G. 1997. Metabolism of a 5-nitroimidazole in susceptible and resistant isogenic strains of Bacteroides fragilis. Antimicrob. Agents Chemother. 41:1495-1499.

Corpet, F. 1988. Multiple sequence alignment with hierarchical clustering. Nucleic Acids Res. 16:10881-10890.

Corton, J. M., Gillespie, J. G., and Hardie, D. G. 1994. Role of the AMPactivated protein kinase in the cellular stress response. Curr. Biol. 4:315-324.

Corton, J. M., Gillespie, J. G., Hawley, S. A., and Hardie, D. G. 1995. 5aminoimidazole-4-carboxamide ribonucleoside. A specific method for activating AMP-activated protein kinase in intact cells? Eur. J. Biochem. 229:558-565.

David, M., Daveran, M. L., Batut, J., Dedieu, A., Domergue, O., Ghai, J., Hertig, C., Boistard, P., and Kahn, D. 1988. Cascade regulation of nif gene expression in Rhizobium meliloti. Cell 54:671-683.

David, M., Domergue, O., Pognonec, P., and Kahn, D. 1987. Transcription patterns of Rhizobium meliloti symbiotic plasmid pSym: Identification of nifA-independent fix genes. J. Bacteriol. 169:2239-2244.

de Philip, P., Batut, J., and Boistard, P. 1990. Rhizobium meliloti FixL is an oxygen sensor and regulates Rhizobium meliloti nifA and fixK genes differently in Escherichia coli. J. Bacteriol. 172:4255-4262.

Ditta, G., Virts, E., Palomares, A., and Kim, C. H. 1987. The nifA gene of Rhizobium meliloti is oxygen regulated. J. Bacteriol. 169:3217-3223.

Eggink, G., Engel, H., Vriend, G., Terpstra, P., and Witholt, B. 1990. Rubredoxin reductase of Pseudomonas oleovorans. Structural relationship to other flavoprotein oxidoreductases based on one NAD and two FAD fingerprints. J. Mol. Biol. 212:135-142.

Finan, T. M., Hartweig, E., LeMieux, K., Bergman, K., Walker, G. C., and Signer, E. R. 1984. General transduction in Rhizobium meliloti. J. Bacteriol. 159:120-124.

Finnemann, J., and Schjoerring, J. K. 2000. Post-translational regulation of cytosolic glutamine synthetase by reversible phosphorylation and 14-33 protein interaction. Plant J. 24:171-81.

Foussard, M., Garnerone, A. M., Ni, F., Soupene, E., Boistard, P., and Batut, J. 1997. Negative autoregulation of the Rhizobium meliloti fixK gene is indirect and requires a newly identified regulator, FixT. Mol. Microbiol. 25:27-37.

Garnerone, A. M., Cabanes, D., Foussard, M., Boistard, P., and Batut, J. 1999. Inhibition of the FixL sensor kinase by the FixT protein in $\mathrm{Si}$ norhizobium meliloti. J. Biol. Chem. 274:32500-32506.

Gilles-Gonzalez, M. A., Ditta, G. S., and Helinski, D. R. 1991. A haemoprotein with kinase activity encoded by the oxygen sensor of Rhizobium meliloti. Nature 350:170-172.

Glaab, J., and Kaiser, W. M. 1993. Rapid modulation of nitrate reductase in pea roots. Planta 191:173-179.

Gouet, P., Courcelle, E., Stuart, D. I., and Metoz, F. 1999. ESPript: Analysis of multiple sequence alignments in PostScript. Bioinformatics 15:305-308.

Henin, N., Vincent, M. F., Gruber, H. E., and Van den Berghe, G. 1995. Inhibition of fatty acid and cholesterol synthesis by stimulation of AMPactivated protein kinase. FASEB (Fed. Am. Soc. Exp. Biol.) J. 9:541546.

Huber, S. C., and Kaiser, W. M. 1996. 5-Aminoimidazole-4-carboxamide riboside activates nitrate reductase in darkened spinach and pea leaves. Physiol. Plant. 98: 833-837.

Kaiser, W. M., and Huber, S. C. 2001. Post-translational regulation of nitrate reductase: mechanism, physiological relevance and environmental triggers. J. Exp. Bot. 52:1981-1989.

Kaneko, T., Nakamura, Y., Sato, S., Asamizu, E., Kato, T., Sasamoto, S., Watanabe, A., Idesawa, K., Ishikawa, A., Kawashima, K., Kimura, T. Kishida, Y., Kiyokawa, C., Kohara, M., Matsumoto, M., Matsuno, A., Mochizuki, Y., Nakayama, S., Nakazaki, N., Shimpo, S., Sugimoto, M., Takeuchi, C., Yamada, M., and Tabata, S. 2000. Complete genome structure of the nitrogen-fixing symbiotic bacterium Mesorhizobium loti. DNA Res. 7:331-338.

Labes, M., Puhler, A., and Simon, R. 1990. A new family of RSF1010-derived expression and lac-fusion broad-host-range vectors for gramnegative bacteria. Gene 89:37-46.

Man, H. M., and Kaiser, W. M. 2001. Increased glutamine synthetase activity and changes in amino acid pools in leaves treated with 5-aminoimidazole-4-carboxiamide ribonucleoside (AICAR). Physiol. Plant. 111:291-296

Maniatis, T., Fritsch, E., and Sambrook, J. 1982. Molecular Cloning: A Laboratory Manual. Cold Spring Harbor Laboratory. Cold Spring Harbor, NY, U.S.A.

Miller, J. H. 1972. Experiments in Molecular Genetics. Cold Spring Harbour Laboratory, Cold Spring Harbor, NY, U.S.A 
Moller, W., and Amons, R. 1985. Phosphate-binding sequences in nucleotide-binding proteins. FEBS (Fed. Eur. Biochem. Soc.) Lett. 186:1-7.

Moorhead, G., Douglas, P., Cotelle, V., Harthill, J., Morrice, N., Meek, S., Deiting, U., Stitt, M., Scarabel, M., Aitken, A., and MacKintosh, C. 1999. Phosphorylation-dependent interactions between enzymes of plant metabolism and 14-3-3 proteins. Plant J. 18:1-12

Newman, J. D., Rosovitz, M. J., and Noel, K. D. 1995. Requirement for rhizobial production of 5-aminoimidazole-4-carboxamide ribonucleotide (AICAR) for infection of bean. Mol. Plant-Microbe Interact. 8:407414.

Niel, C., Guillaume, J. B., and Bechet, M. 1977. Demonstration of 2 enzymes with beta-galactosidase activity in Rhizobium meliloti. Can. J. Microbiol. 23:1178-1181.

Prentki, P., and Krisch, H. M. 1984. In vitro insertional mutagenesis with a selectable DNA fragment. Gene 29:303-313.

Quandt, J., and Hynes, M. F. 1993. Versatile suicide vectors which allow direct selection for gene replacement in gram-negative bacteria. Gene 127:15-21.

Renalier, M. H., Batut, J., Ghai, J., Terzaghi, B., Gherardi, M., David, M., Garnerone, A. M., Vasse, J., Truchet, G., and Huguet, T. 1987. A new symbiotic cluster on the pSym megaplasmid of Rhizobium meliloti 2011 carries a functional fix gene repeat and a nod locus. J. Bacteriol. 169:2231-2238.

Reyrat, J. M., David, M., Blonski, C., Boistard, P., and Batut, J. 1993. Oxygen-regulated in vitro transcription of Rhizobium meliloti nifA and fixK genes. J. Bacteriol. 175:6867-6872.

Rosenberg, C., Boistard, P., Denarie, J., and Casse-Delbart, F. 1981. Genes controlling early and late functions in symbiosis are located on a megaplasmid in Rhizobium meliloti. Mol. Gen. Genet. 184:326-333.

Rossmann, M. G., Moras, D., and Olsen, K. W. 1974. Chemical and biological evolution of nucleotide-binding protein. Nature 250:194-199.

Schubert, K. R. 1986. Product of biological nitrogen fixation in higher plants: Synthesis, transport, and metabolism. Annu. Rev. Plant Physiol. 37:539-74.

Smith, D. R., Doucette-Stamm, L. A., Deloughery, C., Lee, H., Dubois, J. Aldredge, T., Bashirzadeh, R., Blakely, D., Cook, R., Gilbert, K., Harrison, D., Hoang, L., Keagle, P., Lumm, W., Pothier, B., Qiu, D., Spadafora, R., Vicaire, R., Wang, Y., Wierzbowski, J., Gibson, R., Jiwani, N., Caruso, A., Bush, D., and Reeve, J. N. 1997. Complete genome sequence of Methanobacterium thermoautotrophicum deltaH: Functional analysis and comparative genomics. J. Bacteriol. 179:71357155.

Soberón, M., Lopez, O., Miranda, J., Tabche, M. L., and Morera, C. 1997. Genetic evidence for 5-aminoimidazole-4-carboxamide ribonucleotide (AICAR) as a negative effector of cytochrome terminal oxidase cbb3 production in Rhizobium etli. Mol. Gen. Genet. 254:665-673.

Soberón, M., Morera, C., Kondorosi, A., Lopez, O., and Miranda, J. 2001. A purine-related metabolite negatively regulates fixNOQP expression in Sinorhizobium meliloti by modulation of fixK expression. Mol. PlantMicrobe Interact. 14:572-6.
Soupene, E., Foussard, M., Boistard, P., Truchet, G., and Batut, J. 1995. Oxygen as a key developmental regulator of Rhizobium meliloti N2fixation gene expression within the alfalfa root nodule. Proc. Natl. Acad. Sci. U.S.A. 92:3759-3763.

Spiro, S., and Guest, J. R. 1990. FNR and its role in oxygen-regulated gene expression in Escherichia coli. FEMS (Fed. Eur. Microbiol. Soc.) Microbiol. Rev. 6:399-428.

Sullivan, J. E., Brocklehurst, K. J., Marley, A. E., Carey, F., Carling, D. and Beri, R. K. 1994. Inhibition of lipolysis and lipogenesis in isolated rat adipocytes with AICAR, a cell-permeable activator of AMP-activated protein kinase. FEBS (Fed. Eur. Biochem. Soc.) Lett. 353:33-36.

Toroser, D., Athwal, G. S., and Huber, S. C. 1998. Site-specific regulatory interaction between spinach leaf sucrose-phosphate synthase and 14-3-3 proteins. FEBS (Fed. Eur. Biochem. Soc.) Lett. 435:110-114.

Townson, S. M., Boreham, P. F., Upcroft, P., and Upcroft, J. A. 1994. Resistance to the nitroheterocyclic drugs. Acta Trop. 56:173-194.

Trinh, S., and Reysset, G. 1997. Identification and DNA sequence of the mobilization region of the 5-nitroimidazole resistance plasmid pIP421 from Bacteroides fragilis. J. Bacteriol. 179:4071-4074.

Truchet, G., Debelle, F., Vasse, J., Terzaghi, B., Garnerone, A. M. Rosenberg, C., Batut, J., Maillet, F., and Denarie, J. 1985. Identification of a Rhizobium meliloti pSym2011 region controlling the host specificity of root hair curling and nodulation. J. Bacteriol. 164:1200-1210.

Tsai, J. W., and Alley, M. R. 2001. Proteolysis of the Caulobacter McpA chemoreceptor is cell cycle regulated by a ClpX-dependent pathway. J. Bacteriol. 183:5001-5007.

Tzivion, G., and Avruch, J. 14-3-3 Proteins: Active cofactors in cellular regulation by serine/threonine phosphorylation. J. Biol. Chem. In press.

Vallon, O. 2000. New sequence motifs in flavoproteins: evidence for common ancestry and tools to predict structure. Proteins 38:95-114.

Vincent, M. F., Bontemps, F., and Van den Berghe, G. 1992. Inhibition of glycolysis by 5-amino-4-imidazolecarboxamide riboside in isolated rat hepatocytes. Biochem. J. 281:267-272.

Vincent, M. F., Marangos, P. J., Gruber, H. E., and Van den Berghe, G. 1991. Inhibition by AICA riboside of gluconeogenesis in isolated rat hepatocytes. Diabetes 40:1259-1266.

Wierenga, R. K., Terpstra, P., and Hol, W. G. 1986. Prediction of the occurrence of the ADP-binding beta alpha beta-fold in proteins, using an amino acid sequence fingerprint. J. Mol. Biol. 187:101-107.

Zalkins, H., and Nygaard, P. 1996. Pages 561-579 in: Biosynthesis of Purine Nucleotide in Escherichia coli and Salmonella, 2nd ed. F. C. Neidhardt ed. ASM Press, American Society for Microbiology, Washington, D.C.

\section{AUTHOR-RECOMMENDED INTERNET RESOURCES}

Kazusa DNA Research Institute Rhizobia database: www.kazusa.or. jp/rhizobase/

INRA Sinorhizobium meliloti strain 1021 Genome Project: sequence. toulouse.inra.fr/meliloti.htm 